\title{
Review: Can Toxic Substances Initiate Psychotic Behavior? Part II. Organophosphate (OP) Substances with Anti-Acetylcholinesterase Enzyme Activity
}

\author{
Ilia Brondz \\ Norwegian Drug Control and Drug Discovery Institute (NDCDDI) AS, Ski, Norway \\ Email: ilia.brondz@gmail.com
}

Received 20 August 2015; accepted 12 October 2015; published 15 October 2015

Copyright (C) 2015 by author and Scientific Research Publishing Inc.

This work is licensed under the Creative Commons Attribution International License (CC BY). http://creativecommons.org/licenses/by/4.0/

(c) (i) Open Access

\begin{abstract}
This article is an extension of a discussion started in the first part of a series of review articles, entitled "Can Toxic Substances Initiate Psychotic Behavior? Part I. Antimalarial Drugs" in (Open Journal of Preventive Medicine). In the present manuscript, the environmental, health, reproduction (fecundity), social, and juridical problems, together with the medical and ethical aspects of the use of organophosphate substances, will be discussed. This article is based mainly on the results of experiments conducted during the period of 2004-2014. The results described in the article entitled "High-Performance Liquid Chromatography (HPLC) Equipped with a Neurophysiological Detector (NPD) as a Tool for Studying Olfactory System Intoxication by the Organophosphate (OP) Pesticide Diazinon and the Influence of OP Pesticides on Reproduction" (International Journal of Analytical Mass Spectrometry and Chromatography) will be discussed in connection to human disability (invalidation) caused by OPs. The results showed that even a short-time, sub-lethal exposure to the anti-acetylcholinesterase enzyme OPs yields altered neural signaling. These perverse nervous signals can change the basic information that is transmitted to the brain. This information regarding the external environment surrounding situation is vital for living organisms. The exposure of organisms to OPs can have a lifelong impact on the nervous system and be a source of adverse psychotic reactions, even after a single exposure. This article stresses the need for a moratorium on (or, even better, the prohibition of) the use of OPs in agricultural and veterinary practices as pesticides, and the recognition of the use of OPs against the civilian population as chemicals to control protests and demonstrations (as protesto- and demonstrationocides) as a criminal act.
\end{abstract}

\section{Keywords}

Suppression of a Population, Suppression of Individual Sexual Activity, Organophosphate (OP)

How to cite this paper: Brondz, I. (2015) Review: Can Toxic Substances Initiate Psychotic Behavior? Part II. Organophosphate (OP) Substances with Anti-Acetylcholinesterase Enzyme Activity. Voice of the Publisher, 1, 47-65. 
Pesticides, Organophosphate (OP) Substances, Endocrine Disruptors, Neuro-Destructive Agents, Psychotropic Destructive Agents, Protests- and Demonstrationocides

\section{Introduction}

\subsection{At the Beginning}

This article is an extension of a discussion started in the first part of a series of review articles, entitled "Can Toxic Substances Initiate Psychotic Behavior? Part I [1]. This paper is based mainly on the results of experiments conducted during the period of 2004-2014, described in [2]-[7]. The term organophosphate (OP) has a specific meaning as insecticides and as nerve agents in warfare. The experiments carried out by Brondz [7] were logical and hypothesis-based. The first experiments on, and positive support for, the hypothesis of the destructive action of OP substances (against nerve physiology and anatomy, endocrine and psychophysiological processes, and the general health status of exposed living creatures, including humans) were obtained when the author worked as the Chief of the Bioanalytic Chemistry and Toxicology Laboratory at the Department of Biology, University of Oslo, Norway, and as the Director of Jupiter AS, Norway, which is a company that provides analytical support to the pharmaceutical industry.

The deep involvement of pesticides and insecticides in the normal physiological process of all living creatures, including plants and mammals, is obvious. The selectivity of these substances toward target organisms (compared with their toxic effects on other non-target living systems) is very low. Often, the toxicity toward a group of pest species covers a broad range of other species that are not meant to be intoxicated. The OP pesticides belong to this group of substances. Pesticides often have other unpredicted toxic side effects [8].

This project was started by the invitation of the author of this review article to help the team of scientists regarding the isolation and molecular elucidation of an elusive pheromone described by K. von Frisch in 1942 [9] and named Schreckstoff by him. At the present time, this substance is known as an Alarm Substance. Prof. Døving was the leading specialist in single-unit registration at the University of Oslo [10]; he was also the head of a laboratory that contained the equipment necessary for recording single-unit signals, which were used to study the effects of Alarm Substance(s) on fish. The author received substantial training from Dr. Hamdani in fish surgery and the recording of signals using the hardware and software of the instrumentation required for this process. From the very beginning, it was clear that Alarm Substance(s) that are found in water and have physiological effects on fish are present at extremely low concentrations. Thus, instrumentation with a much more powerful detection sensitivity than that available at the time was necessary. This equipment was constructed based on HPLC [2] [3] and the available software described in these articles and the olfactory system of the living fish Carassius carassius L. The further development of this system is described in [6] and [7].

The interest in the results presented by the initial project in publications [2]-[5] was enormous, and, for further development of the system, the team under the leadership of Prof. Døving and the author requested 250,000 Norwegian kroner (Nkr) ( 50,000 USD) per year from the Norwegian Research Council. However, because of the interest demonstrated by the Norwegian fishery and fish-farming industries, the team received 450,000 $\mathrm{Nkr}$ ( 90,000 USD) per year. All resources were regrettably placed in the hands of Prof. Døving, who invested them in stipends for students (of the female sex). The author's request that Prof. Døving's needs for students (of the female sex) should be somewhat restricted-because the development of the project required chemicals, some modification of instrumentation, and additional laboratory equipment-was dismissed by Prof. Døving. The collaboration with the team of Prof. Døving was interrupted and ended at this stage; however, the project was continued in the laboratories of Jupiter AS, Norway, and later at the facilities of the Norwegian Drug Control and Drug Discovery Institute (NDCDDI) AS, Norway.

\subsection{Who Was Interested in the Project?}

The primary interest came from the fishery and fish-farming industries, because of the design of the experiments. The population of wild salmon coming to Norwegian fiords, rivers, and lakes had been diminishing in the past decades. A similar tendency was observed for other fish populations. Explanations for this phenomenon, such as overfishing and "climate changes", could of course be accepted; however, the experts are well aware that other more powerful factors exist, such as the low reproducibility of fish schools. The author's interest was in study- 
ing the mechanisms underlying the toxic effect of OPs on the behavior of fish in particular, and on living creatures in general, as (potential) antipheromones, pheromones, and Alarm Substance(s), and their influence on reproducibility; as potential endocrine disruptors; and as neuropsychotropic destructive agents. Specialists in Occupational Medicine were especially interested in the possible effect of OPs on the reproductive health of farmers and industrial workers. Additional interest came from military experts and the police. The possible development of non-lethal weapons, such as Schreckstoffs, was one of the main attractions of this project (for military experts). In some conflict situations, the undermining of the battle mood of the enemy can be more important than the use of excessive force. This attracted the author's attention toward OPs as unlawful protesto- and demonstrationocides, when used as dangerous psychotropic destructive agents.

At the very beginning, OPs attracted the attention of scientists as potent anticholinesterase agents in the struggle against insects and other agricultural pests [11]; however, they also attracted the attention of the Nazis as psychodestructive and life-destructive agents [7].

In the present article, the main discussion will focus on the toxic effects of OPs on behavior, as well as on the destruction of reproducibility and mental ability, and in general the medical invalidation of all creatures, including mammals and humans, by these substances.

\section{Toxicity}

\subsection{Toxicity of OPs}

The toxicity of OPs toward fish and other living creatures is described in [7]. OPs are cholinesterase inhibitors with anti-acetylcholinesterase enzyme activity [12]-[15]. Usually, attention is given to OP absorption through the skin and mucosa; thus, little attention has been given to the fact that OPs can be transported directly to the brain through the olfactory nerves (ONs) via axoplasmic transport [16], by bypassing the liver detoxing barrier. Intoxication of brain nerve structures by axoplasmic transport through ONs can yield irreversible damage in specific regions.

In the minds of nonspecialists, the liver detoxing barrier is associated with real detoxification; that is, the physiological removal of toxic substances from a living organism (e.g., the human body), which is mainly carried out by the liver. However, after microsomal detoxification in the liver, many substances are transformed into more toxic products compared with the original toxins. The oxidation of diazinon to the more toxic diazoxon occurs via the action of light and humidity [7], as well as by microsomal detoxification in the liver. The scheme of microsomal actions in the liver upon exposure to diazinon is given below (Scheme 1). Many toxic OPs as diazinon containing a sulfur atom undergo oxidation to oxons [17]-[22], and their biotransformation yields substances with increased toxicity. Parathion has an analogous ability to be oxidized to paraoxon and yield more toxic oxons [23]-[25] (Scheme 2). The reactions of transformation and biotransformation of phosphorothioates to the corresponding (more toxic) oxons are common among all members of this family of substances, and can be supported by examples of important phosphorothioates: salithion [26] and cyanox [27]. Cyanox gives a corresponding oxon by biotransformation and is also degraded by light to the poison cyanide [27] (Scheme 3). Phosphorodithioates also undergo transformation and biotransformation to more powerful toxins, via oxidation, and give oxons (e.g., malathion) [28] (Scheme 4). Malathion [28] rapidly undergoes biotransformation to malaoxon, which is more than 60 times as toxic as the original pesticide. The other phosphorodithioates are subject to similar transformation and biotransformation reactions, resulting in the formation of more toxic substances compared with the original pesticides.

Halogenated OPs with anti-acetylcholinesterase enzyme activity are used widely. One of them is dichlorvos, which is used as is and is a product of the degradation of the pesticides trichlorfon and naled. The degradation of trichlorfon and naled to dichlorvos, and their transformation and biotransformation, are given in Scheme 5.

\subsection{Mode of Action}

An anti-acetylcholinesterase effect is primarily accepted by the scientific community as the mode of action of these compounds. They attack the peripheral and central nervous systems by inhibiting the acetylcholinesterase (AChE) enzyme [12]. By preventing acetylcholinesterase activity, OPs lead to the accumulation of acetylcholine at high concentrations in the synaptic cleft or the synaptic junction. The muscles, excretory cells, and the brain receive nerve impulses continually. The brain can also be affected directly by OPs via axoplasmic transport through ONs [16] [29]. By this mechanism the direct intoxication of brine is taking place. Because experimental research 


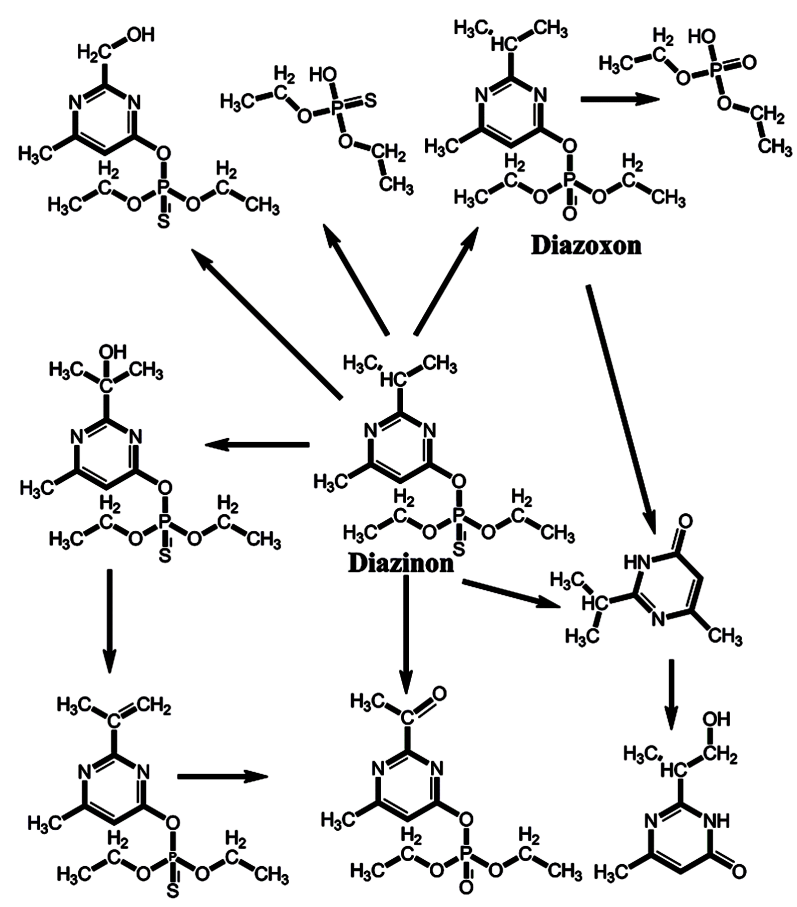

Scheme 1. Microsomal detoxification of diazinon in the liver gives diazoxon and products that are more toxic than the original toxin.

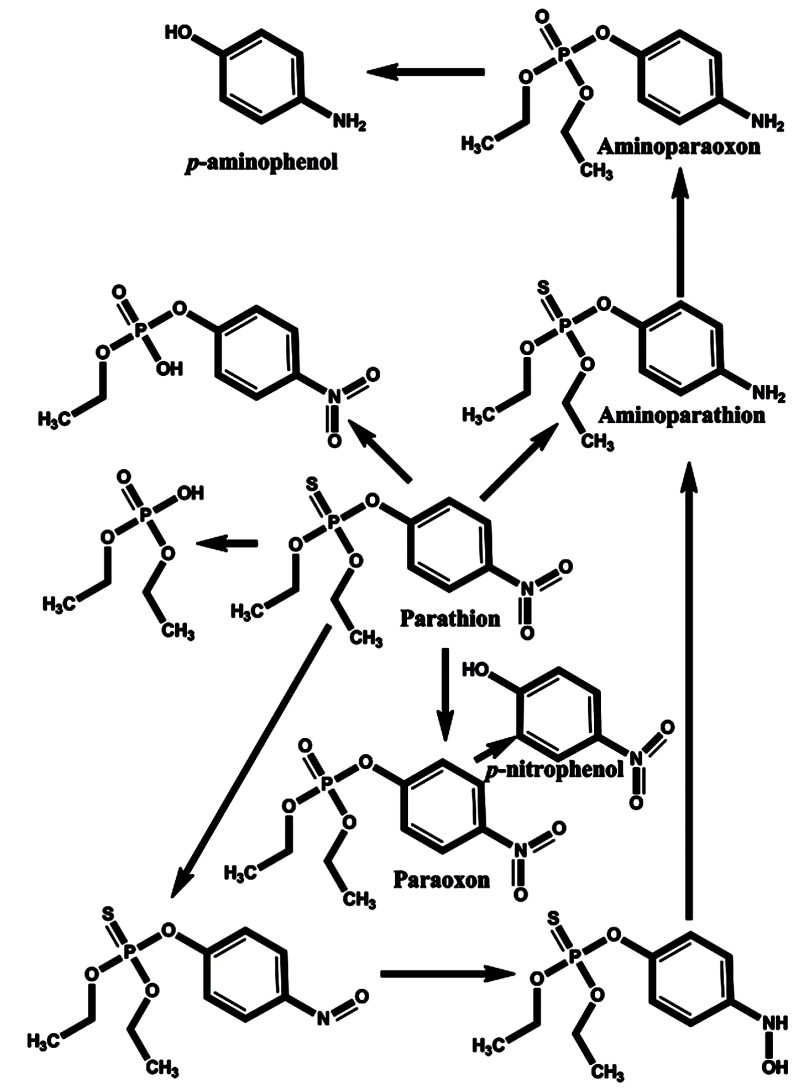

Scheme 2. Microsomal detoxification in the liver gives oxons that are more toxic than the original parathion, such as paraoxon, aminoparathion, aminoparaoxon, $p$-aminophenol, $p$-nitrophenol, and others. 


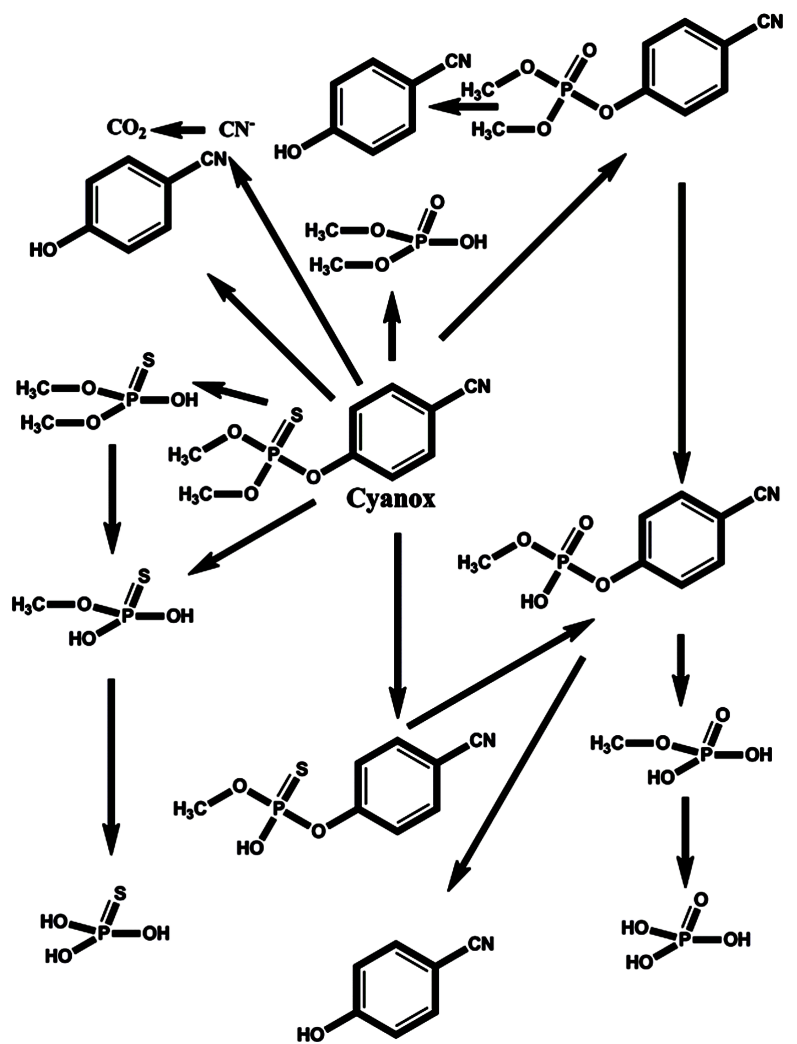

Scheme 3. Cyanox, in addition to the corresponding oxon, is degraded by photolysis to cyanide, which is toxic to the metabolism.

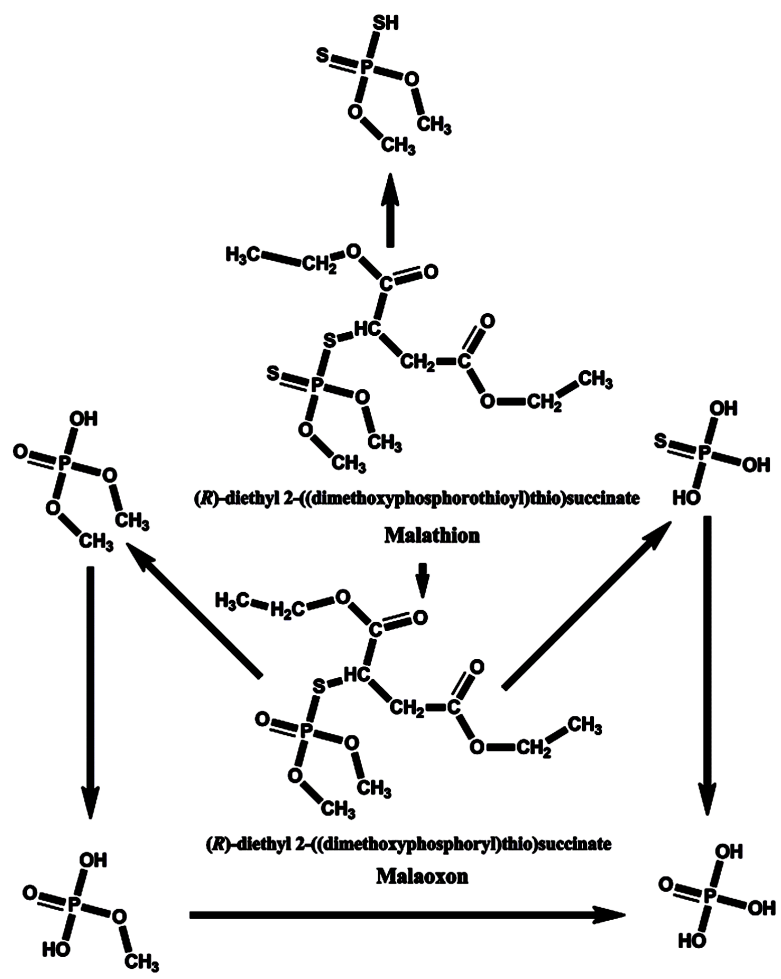

Scheme 4. Transformation and biotransformation of malathion to more toxic substances. 


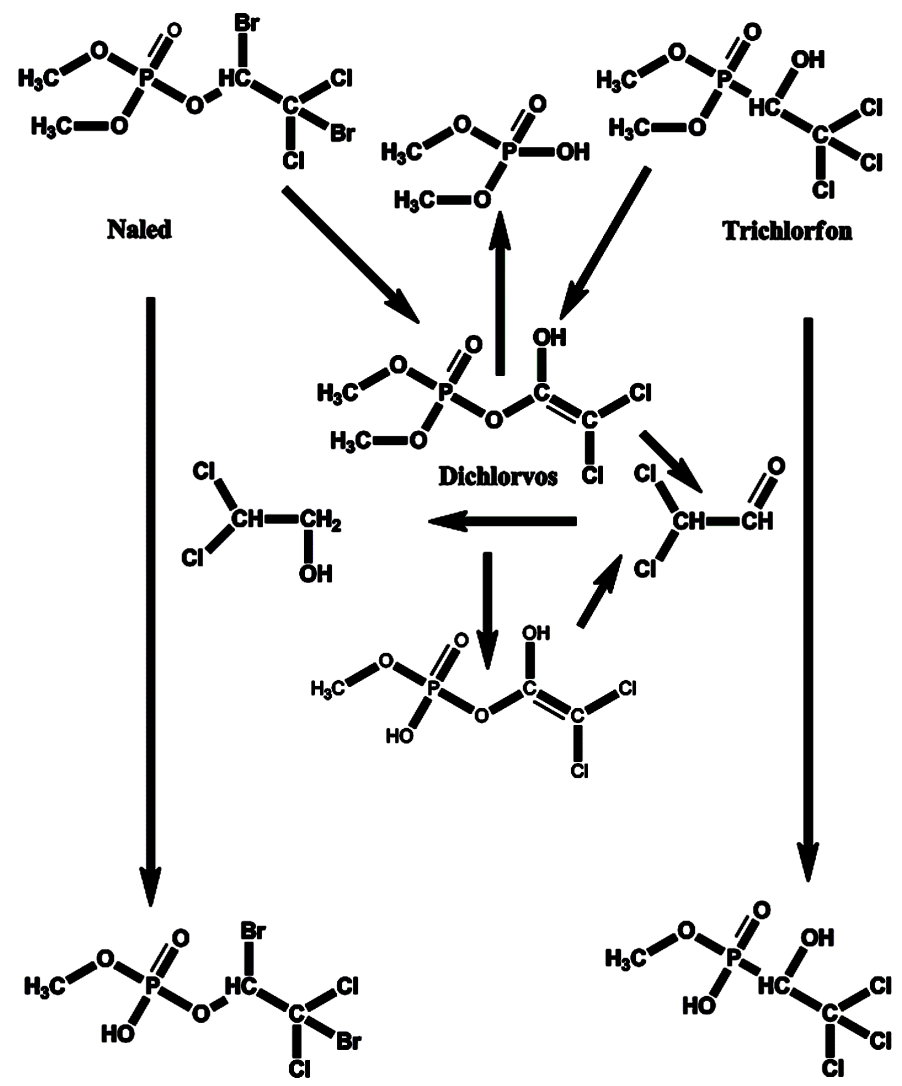

Scheme 5. Degradation of trichlorfon and naled to dichlorvos, and transformation and biotransformation of these OP pesticides and dichlorvos.

regarding intoxication of human volunteers by OPs is nearly absent in the open literature (such information may exist in closed military sources), the insurance agencies speculate freely on this subject, claiming that disability in humans caused by OPs is poorly documented and/or does not exist, which is not correct.

Nonhuman models were used to demonstrate the numerous symptoms of intoxication by OPs and to propose their modes of action [7], [30]-[32]. Numerous reports of cases of human disability caused by OPs, accompanied by symptom description, support the neurotoxicity of these compounds [33]-[36]. The effect of OPs on nervous signals from the nerve cells of the olfactory epithelium to the brain is described in [7], and the toxic influence of OPs on sperm chromatin is described in [37], [38]. OPs directly suppress reproducibility (fecundity) in humans [39], as well as in other living creatures, at the individual and population levels. Exposure to OPs increases the risk of developing several diseases [12] [40], which also affect the fecundity of individuals and populations. Biological and demographic fecundity is the actual reproductive rate, which is heavily affected by pesticides, especially OPs. Therefore, OPs play a significant role in the reduction of the populations of fish that dwell continuously rivers and lakes, as fish that nest regularly in rivers and lakes are affected by agricultural contamination; and agricultural contamination with pesticides play a role in the reduction of the population of Caucasians who first started the broad use of OPs in farming and aquaculture and applied them as warfare agents and protestoand demonstrationocides for subduing the civilian population. The OP substances are endocrine disruptors that can suppress the fecundity of populations and lead to demographic disasters. The most important of these effects are the neuropsychopathological changes that are induced by OPs [41]. Significant changes in the behavior of workers exposed to OPs are reported in [42]. It is claimed in [39]: "Organophosphorus compounds, used as insecticides and agents of chemical warfare, are a major global cause of health problems." The increased toxic potential of OP mixtures has been known since 1957 [43]. Karczmar [44] wrote: “...there is the matter of the Operation Desert Shield (ODS), or the Persian Gulf War that lasted from August 1990 to late February, 1991 and the related Persian Gulf War Syndrome (PGWS) or 'mystery illness'... Soon thereafter a significant number of returning veterans complained of a variety of symptoms; later, a certain pattern and certain characteristics of 
these symptoms could be discerned and suspicion arose as to the possible causes of the syndrome, including exposure to OP agents, whether via Iraqi attacks on U.S.A. forces or via other means."

Before ODS, most of the publications stemmed from developing countries that described cases of human intoxication and problems connected to OP use in farming [30]-[32]. One of the explanations for sources (developing countries) of these observations may be the resistance offered by pesticide manufacturers and insurance companies to the subsidizing in the developed countries research that will report strong evidence of disabilities affecting workers in chemical industries, farming, and agriculture. The latest reports suggest that OPs are involved in intoxication at the DNA level, as demonstrated by statements such as "pesticides showed stronger interaction with AMP... which could lead to problems in the DNA replication and biological functions of nucleotides" [45].

\section{Olfactory System}

\subsection{Olfactory Organ Organization}

"Despite minor anatomical differences, the general principles and computations performed by the fish olfactory system are highly similar to what is described in terrestrial vertebrates" [46].

The organization of the olfactory organs in fish species can be presented as a sequence of structures: the olfactory epithelium (OE) (Figure 1), olfactory bulb (OB), and olfactory nerves (ONs), which lead to brain structures such as the telencephalon (TE), dorsal-posterior part of the telencephalon (Dp), habenula ( $\mathrm{Hb})$, ventral nucleus of the ventral telencephalon $(\mathrm{Vv})$, optic tectum $(\mathrm{OT})$, posterior tubercle $(\mathrm{PT})$, hypothalamus $(\mathrm{HT})$, cerebellum (CB), mesencephalic locomotor region, reticulospinal tract (RST), and spinal cord (SC) (Figure 1).

Nasal mucosa are divided into two areas: the respiratory region and the olfactory region, which contains the sensory cells. In fish as well as in mammals, the olfactory receptors (ORs) are located in the nasal cavity (nose). The olfactory organ is a binary organ; fish have two nasal cavities (nostrils). The olfactory epithelium lies between these two nostrils [47]. For fish, water carries odorants and signal molecules; water enters the nose and exits it through a posterior nostril. The axons of the sensory cells enter the olfactory bulb. Mitral cells lead their axons through ONs via the fibers of the medial and lateral olfactory tracts to the forebrain (the olfactory lobe of the brain). The three anatomically and physiologically distinct olfactory tracts can be differentiated: the lateral olfactory tract contains mainly fibers that originate in the lateral olfactory bulb, whereas the medial olfactory tract is subdivided into medial and lateral tracts [48]-[51]. The anatomical separation of the medial and lateral olfactory tracts into well-defined axon bundles enables the research of the neurophysiology of olfactory signal processing [2]-[7] [52] [53] (Figure 2).

\subsection{Olfactory System Genesis and Importance}

As mentioned by Joy V. Browne: "The chemosensory system is one of the earliest emerging systems in fetal development..." [54]. Of course, this was written in relation to humans, among whom the relevant "Anatomical structures and innervation are already present in the first and early second trimesters..." [54]. This is also correct in most living creatures: these structures "...not only have a profound effect on how environmental information is detected and processed but also make significant contributions to cognitive and emotional interpretation of daily experiences..." [54]. About $90 \%$ of the emotional information that reaches the fetus is canalized by the chemosensory system. The sensory organs of fish that are responsible for smell detection and information processing have been studied in [7] [9] [55]-[61]. Von Frisch, in [9] [62], connected information received by the

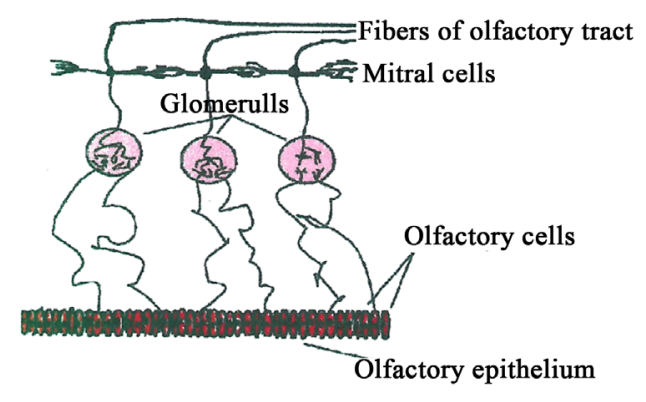

Figure 1. The organization of the olfactory organ. 


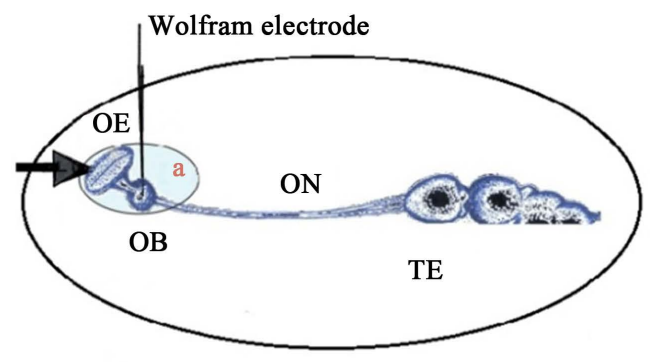

(A)

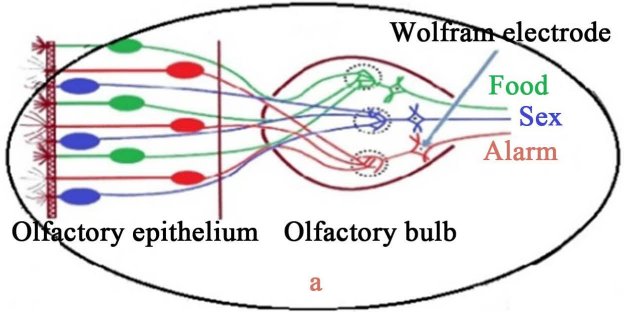

(B)

Figure 2. From the left in part (A): neurophysiological cell(s) used in the experiments described in [2]-[7]. Aa: olfactory epithelium (OE) and olfactory bulb (OB) with a recording tungsten electrode. The olfactory nerves ON are shown as distinct olfactory tracts: the medial and lateral olfactory tracts, which lead axons to the forebrain; (B) from the right in part a: scheme showing the placement of the tungsten electrode in olfactory bulb cell(s). These axon(s) are leading nerve impulses of alarm. The scheme of the experiments described in [7] is shown in Figure 3.

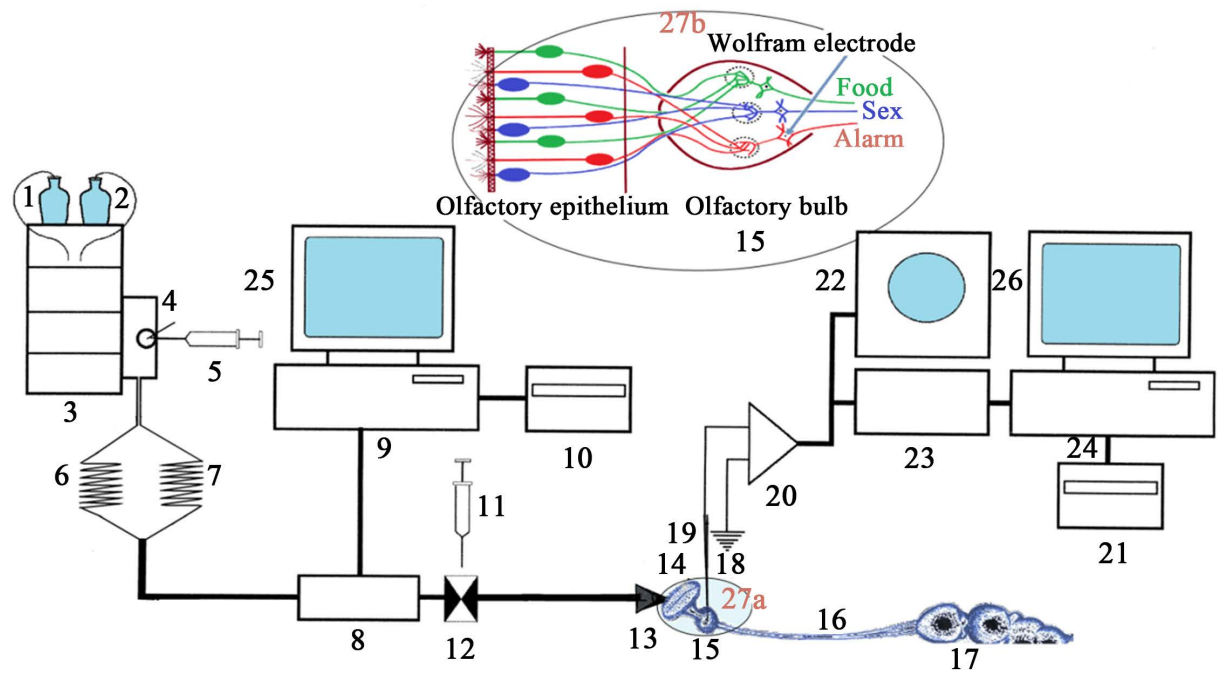

Figure 3. A schematic drawing of the experimental setup of the HPLC equipped with DAD and NPD. The setup included (1) reagent bottle 1 with APW; (2) reagent bottle 2 with APW with 10 ppm of diazinon; (3) the HPLC system; (4) a Rheodyne injector; (5) a syringe with a mixture of sex hormones; (6) column 1; (7) column 2; (8) the DAD; (9) a data processor for the HPLC system; (10) data acquisition printer 1 for the HPLC system; (11) a syringe with fish skin extract; (12) a microvalve; (13) transference tubing; (14) OE; (15) OB; (16) olfactory tract; (17) telencephalon; (18) an earth ground connection; (19) a tungsten electrode; (20) an amplifier; (21) data acquisition printer 2 for the NPD; (22) an oscilloscope; (23) an AD converter; (24) a data processor for the NPD system; (25) a PC screen for the HPLC; (26) a PC screen for the NPD; (27a) the active detection part of the NPD; and (27b) the active detection part of the NPD, in detail. Courtesy to the International Journal of Analytical Mass Spectrometry and Chromatography, published by Scientific Research Publishing Inc., USA, to Jupiter AS, Norway, and to the Norwegian Drug Control and Drug Discovery Institute (NDCDDI) AS, Norway, for granting permission to reproduce the figure from publication [7].

chemosensory system to distinct behavioral patterns. In fish, the chemosensory system has direct informative influence on feeding, sexual, and antipredator behaviors, the same being true in mammals, including humans. Sex is the most important driving force for the reproduction and preservation of species populations [63]. In all species, the sexual drive and offspring preservation instinct prevail over hunger and even the instinct of self-preservation.

Dogs have 230 - 250 million olfactory receptor cells; the average human has fewer than 10 million. Generally, this is true for all primates. It has been accepted for a long time that humans and other primates are typically microsmatic (i.e., worse smellers), and that, in humans, the production, recognition by the olfactory system, and reaction on sex pheromones and other natural pheromones are absent. "This concept needs reconsideration since many recent studies have shown that olfaction plays a very important role in human reproductive biology and 
because human reproductive biology affects human behavior" [64]. Olfactory stimuli can provoke strong emotional responses as a reaction to distinct chemical substances (pheromones), such as aggression [65], sexual drive [64], avoidance/hiding [9], [62], self-preservation, etc. "Olfactory input from the social environment is well adapted to fit such assertions. For example, chemical cues allow humans to select for, and to mate for, traits of reproductive fitness that cannot be assessed simply from visual cues" [64].

\section{Pheromones}

\section{Discovery and Actions}

Peter Karlson and Martin Lüscher introduced the term "pheromone" in 1959. This word is composed of two an-

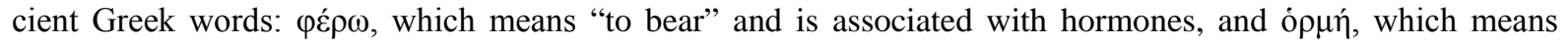
"impetus" and is associated with secreted or excreted substances. Pheromones are sometimes named as ecto-hormones; however, they can perform other functions as well. Among the earlier researchers of pheromones, the French entomologist Jean-Henri Fabre (1823-1915), the American entomologist Joseph A. Lintner (1822-1898), the German biochemist Adolf Butenandt (1903-1995), and the Austrian ethologist Karl von Frisch (1886-1982) should be mentioned. Pheromones are often products of the oxidation or biotransformation of original substances. Oxidation and biotransformation are mainly carried out by microorganisms, as in the case of human sex pheromones: "It is important to note that the odors arise only via the activity of microorganisms" [64], [66] [67]. The pheromone class includes biological substances with different aims and physiological mechanisms and must be carefully re-examined and divided into more specific biological triggers of behaviors, such as: sex attractants, sex suppressors (sterilants) [68], alarm-defense agents, mood triggers (aggressins or offensins) [69], etc.

In social insects, such as ants and many other insects, individual and social behavior and even the physiology of individuals and their partners are regulated by pheromones. Social insects use these chemical substances for communication and for governing the physiology of their "cocitizens" in a colony. The pheromone 3-methylhentriacontane $\left(3-\mathrm{MeC}_{31}\right)$ of the queen regulates worker sterility and aggressive behavior in the ant Lasius niger [68] [70]-[74].

Pheromones are produced by all living organisms to facilitate communication, and this is true of both one-cell and multicellular organisms, including humans. The odors (pheromones) of flora should be carefully re-examined. Mushrooms, fungi, algae, and green plants produce odors for communication. The perception that pheromones are aimed strictly for conspecific communication is erroneous; some pheromones are conspecific, whereas others are aimed at communicating with other species. Pheromones and antipheromones have physiological effects on living organisms that are wider than merely their communicative functions. These pheromones have been best studied in worker honey bees (Apis mellifera L.). Their foraging activity is regulated by pheromones from the queen [75]. The queen modulates brain function in worker honey bees by using pheromones [76], and her pheromones even block aversive learning in young worker bees [77]. None of these substances has communication functions; rather, they perform governing or subduing functions. It is obvious that, in aquatic organisms, it is important to produce water-soluble pheromones for communication; moreover, often, these should be long-lasting substances as the homing place markers. In terrestrial organisms, the production of volatile substances is important; however, some revere (revere - the area of space, air or water over any territory occupied and protected by animal) or sex markers should persist over a long period of time. Because of this needs, the pheromones need to be mixed with the help substances as fixatives [78]. Social insects have a highly developed system of chemical communication, governing, and subduing [79]-[81]. Other social animals, such as fish, birds [82], and mammals [83] [84], including primates [85], also have sophisticated systems of communication, governing, and subduing, including reproductive suppression [86]. It is difficult to believe that humans, which are relatives of primates and thus social animals, lack the natural pheromones of communication, governing, and subduing, including reproductive suppression. In human societies, maybe governing and subduing, including reproductive suppression, have a more profound expression via direct physical actions and synthetic chemicals; such examples are well known from the Bible (genocide of the Israelites by the Pharaoh of Egypt), and even before this from ancient Assyrian and Hittite sources dated 3000 years B.C.E. (i.e., evidence of genocide against conquered peoples). The most profound examples come from history: the destruction of Jericho by Judas, the destruction of Phoenician Tyre by the Greco-Macedonians, the destruction of Phoenician Carthage (Latin: Carthago or Karthago,

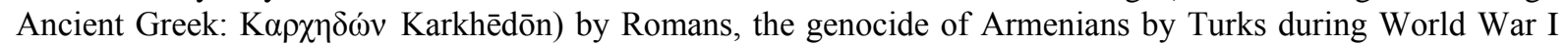
(WWI; physically), the genocide of the Jewish people by Germans during WWII (physical and chemical killing, 
and sterilization by X-ray, chemicals, and other means), the genocide of the native population of Cambodia by the Khmer-Rouge (by all means a primitive physical destruction), the genocide in Rwanda of Tutsis and moderate Hutus by members of the Hutu majority (physically), etc.

Human social behavior is somewhat also regulated by odors (pheromones) [87] [88].

\section{The History, Regulation, and Reality of Chemical Weapons of Mass Destruction}

The OPs under discussion in this paper are the agricultural and warfare nerve agents that are related or may be related to the experiments described in [7]. OPs are synthetic substances with anti-acetylcholinesterase enzyme activity. The first synthetic cholinesterase inhibitor, tetraethyl pyrophosphate (TEPP), was synthesized in Adolphe Wurtz's laboratory in Paris by Philippe de Clermont and Wladimir P. Moshnin in 1854 [11], [89]. The toxic effects of OPs on the nervous system were discovered in 1932 by Willy Lange (1900-1976) and Gerda von Krueger (1907-1970) [90]. OP compounds used as chemical weapons have been classified as weapons of mass destruction by UN Resolution 687 (https://www.google.com/\#q=un+resolution+687+summary). This resolution is the extension of the Protocol for the Prohibition of the Use in War of Asphyxiating, Poisonous or Other Gases, and of Bacteriological Methods of Warfare adopted in 1925 in Geneva under the auspices of the League of Nations from May 4 to June 17, 1925. The Protocol entered into force on February 8, 1928

(http://www.un.org/disarmament/WMD/Bio/1925GenevaProtocol.shtml). This resolution was adopted after the horrors of the use of gas warfare in WWI [91].

Despite the adoption of the Geneva Protocol in 1925, during WWII, Nazi Germany and Japan used chemical and bacteriological methods of warfare, mostly against the civilian population [92], [93]. It should be recognized that "The Reich kept strictly to the requirement of the Versailles dictate regarding chemical warfare equipment. Even the Weimar Republic kept to the dictate. During the Sea Disarmament Conference, 1921/22, in Washington, the following nations did not agree to gas or any chemical weapons being dangerous weapons: USA, England, France, Japan and Italy" [94]. Even later in 1925 in Geneva, a significant number of countries did not agree to adopt this so-called Geneva Gas-War Protocol: "Out of the 44 nations attending the Geneva conference 38 had, by the end of 1935, signed the protocol. 21 nations took reservation, 17 were reluctant. By the end of 1935, 28 nations had ratified the convention. But 10 refused; among those were USA, Japan, Czechoslovakia, Luxemburg, and various nations in South America. The Reich signed without any reservations" [94]. The first country that used a chemical weapon on the battlefield during WWII was Poland: "The first incident involving poisonous gas in WWII occurred on the evening of Friday, September 8, 1939 in the village of Jaslo in the south of Poland. (5) Polish troops had tried to blow up a railway bridge over the river Jasiolka. The Poles had used a chemical bomb (6)" [94]. In recent history, the use of chemical weapons was recorded at the Moscow Theater Nord-Ost in Russia during a terrorist hostage crisis [95]. Despite the overall recognition of the illegality of the use of poisonous gases and OPs during military conflicts (Iran and Iraq joined the Geneva Protocol in 1929 and 1931, respectively), evidence of the use of OPs during the Iran-Iraq War (1980-1988) was reported [96]. Later, during the Gulf War (Operation Desert Storm), the military personnel on the battlefield were exposed to OPs and other poisoning chemicals [97] [98].

\section{The Main Point of the Experiment}

The experiment described in [7] was designed to study the correlation between different chemicals that evoked a signal in the olfactory epithelium/bulb before and after the exposure of the olfactory organ to OPs, such as diazinon; and the possible signal misrepresentation after pre-exposure of the olfactory organ to diazinon. The misrepresentation of the signal after pre-exposure of the olfactory organ to diazinon (if it was recorded) should explain, at the neurophysiological level, the behavioral changes observed in fish. Moreover, the fish model should be adopted to explain the neurophysiological basis of the behavioral changes observed in other living creatures, including humans.

The following basic points were known before the experiments:

1) The point of introduction of the tungsten electrode into the olfactory bulb was the medial bundle of the medial olfactory tract (Figure 2(Ba) and Figure 3) [2]-[6] [10] [52] [99] [100]. These nerve cells were selective toward signals evoked by Alarm Substance(s)/Alarm Pheromones.

2) From the point of introduction of the tungsten electrode into the olfactory bulb (medial bundle of the medi- 
al olfactory tract), it was possible to record the signals from one or several similar nerve cells that evoked and sent a response as a reaction to Alarm Substance(s)/Alarm Pheromones [2]-[6] [10] [52] [99] [100].

3) The olfactory cells that are connected to the medial bundle of the medial olfactory tract were not capable of evoking a full-fledged signal as a reaction to Sex Pheromones [7] [52] [99] [101] (Figure 2(Ba) and Figure 3).

4) The behavioral aspect of the response in fish exposed to Alarm Substance(s)/Alarm Pheromones has been studied well [9] [62] [102]-[104].

5) The correlation aspect of the neuroelectrical/behavioral response of fish exposed to Alarm Substance(s)/ Alarm Pheromones has been studied well [2]-[6].

6) The behavioral and health response of fish exposed to OPs has been studied well [105]-[110].

7) The cognitive impairment of living organisms, including humans, by OPs has been documented well [33] [34] [36] [105].

The following points should be studied at [7]:

1) The neuroelectrical response of fish' OE/OB exposed to sex pheromones before exposure to OP.

2) The neuroelectrical response of fish' OE/OB exposed to sex pheromones after exposure to OP.

3) Influence of exposure to OP on cognitive functions.

\section{Cognitive Impairment}

The effect of pheromones on the cognitive abilities of social insects has been documented, especially the ability of the pheromones of the bee's queen to block aversive learning in young worker bees [77]. Because the exact nervous and biochemical mechanisms that underlie this phenomenon are not known, it is possible to accept the hypothesis that the pheromones of the queen are not exceptional chemical substances; rather, there are several other natural and synthetic substances with similar abilities. It is possible to accept the hypothesis of the existence of a class of substances (such as OPs) that slow down, prevent, or misrepresent nervous signals from primary detecting cells and impede their transmission to the central nervous system (CNS), and then prevent to create stable reflexes in the CNS by repetition. It is also possible to accept the hypothesis that this distorts the reflexes of the CNS for certain physical actions, leads to misrepresentation of the external environment in information processing, or leads the CNS to initiate the wrong signals to body organs or subsystems of the CNS. I will henceforth name the substances that have these abilities chimerical, as they represent a chimerizing (misrepresentative) situation. The word chimera (/ki'mırə/or /kaı'mıərə/, also chimaera/chimæra) is from the Greek Xí $\alpha$ aı $\alpha$ (Chímaira), a dangerous mythological creature.

In "Neuropsychopathological Changes by Organophosphorus Compounds" [41], Eyer gives the description of neuropsychopathological changes that were known up to 1995: "Long-term toxic effects affecting behavior as well as mental and visual functions... The number of victims is estimated at some 100.000 per year world-wide" [41]. This may have been correct at that point in time, because he did not have access to all the documentation available. During the Gulf War (August 2, 1990 to February 28, 1991), and the code-named Operation Desert Storm (August 2, 1990 to January 17, 1991), it is claimed in [97] that: "The Jan. 18, 1991, bombings of the munitions plants in Nasiriyah and Khamisiya blew a plume of sarin gas..." and "The gas plumes, the researchers said, can be blamed for symptoms of Gulf War illness, the mysterious ailment that has affected more than 250,000 veterans of the war". The same author describes the action of OPs on the nervous system: “...vertigo, general weakness, drowsiness, lethargy, difficulty in concentrating, slurred speech, confusion, emotional lability and hypothermia are associated with slighter intoxications" [97], and later: "US army volunteers were experimentally exposed to... nerve agent VX.... Cognitive competence as revealed by mathematical tests was significantly reduced only after $1 \mathrm{~h}$ following VX (71\% of the placebo score)."

There is no doubt that exposure to OPs results in cognitive impairments in mammals [111], including humans [112], [113]. In [114], organic damage to the brain is pointed out: "Cabin air in airplanes can be contaminated with engine oil contaminants. These contaminations may contain organophosphates (OPs) which are known neurotoxins to brain white matter."

Exposure to OPs affects cognitive ability in humans [115], even after low-level exposure to OPs. These compounds cause long-lasting damage to neurological and cognitive functions [116]. All evidence suggests that more than 100,000 people are affected by reduced cognition every year, or even more than 250,000 people [97], in contrast to the claims of [41]; in any case, nearly every one of us is affected by OPs at a low level, and all affected persons experience a partial decrease in cognitive ability and nervous stability. 


\section{Discussion}

\subsection{Economic Pros and Contra: Can Insecticides Be Nonharmful?}

The production of food and other agricultural products cannot sustainably feed the global population in the absence of insecticides and rodenticides. In Norway, the fishing and fish-farming industries are an important part of the production of food and food exports. The main product of these industries is salmon. The diminished number of wild salmon coming to the Norwegian rivers and lakes is a problem. The health of fish (salmon) in farming ponds can be maintained by treatment against parasites by using pesticides. A long-term program was initiated for the study of pesticide filtration in the ground water from agricultural fields, as reported in [117]-[119]. In India, one-third of harvests can be destroyed by rodents and insects. Pesticides guard harvests against parasites. However, all pesticides and rodenticides available on the market are highly poisonous. There is a natural rodenticide that is nonharmful to humans and most living creatures. However, for big chemical and pharmaceutical companies that manufacture pesticides, sucha solution is not acceptable. Regarding insecticides, the experiments performed using the house fly Musca domestica L. in our laboratory identified a biodegradable insecticide that has a relatively low toxicity and short-term persistence. An array of insecticides that are nonharmful to mammals, birds, and fish can also be developed.

\subsection{Ethical Aspects}

In [8], the suppression of immunity by some pesticides and their equally harmful consequences for human health generally are discussed. Several other chemicals can cause psychosis. In [1], the possibility that antimalarial drugs cause this state is discussed. The case of the shooting of several soldiers by one of their comrades at Fort Hood, USA, in 2014, was presented by the mass media as follows: "In the press was only mentioned that Iraq veteran kills three people at Texas military base Fort Hood, 16 injured as gunman, who was receiving psychiatric help, went on shooting spree before killing himself. The suspect, a soldier who had served in Iraq, he 'had behavioral health and mental health' issues. There was no known motive for the shooting, the general Milley said" [1].

On this occasion, it is appropriate to ask several questions:

1) How is General Milley qualified to establish the diagnosis that this soldier "had behavioral health and mental health" issues?

2) Why was the ill person with psychiatric problems (who was alleged to have been decommissioned) held on a military base, rather than in a specialized civilian hospital?

3) Was this shooting a unique opportunity to draw attention to the unlawful imprisonment by military authorities of an ill veteran after exposure to toxic substances, such as VX, in Iraq during the Gulf wars?

4) How many ill veterans of the Gulf wars suffer without medical help?

5) Who is concealing the source of the Gulf War Syndrome under a security classification, and why is this occurring?

6) How many soldiers and officers are affected by this mysterious illness?

7) What can be done to help the veterans of the Gulf wars who are affected by this mysterious illness?

\subsection{Juridical Aspects}

The use of poisonous chemicals in warfare is a criminal act that is regulated by [120] and [121]. Often, collateral damage to the civilian population is enormous, as occurred during the Syrian civil war. To the credit of the USA and its allies, their uncompromising position regarding the prevention of the use and dissemination of chemical weapons by the Syrian regime of Assad should be noted. The USA and its allies forced the Syrian regime of Assad toward disarmament and the decommissioning of chemical weapons under international supervision. Contrary to the Iraqi case, the decommissioning in Syria was performed under the supervision of the Unaided Nations Organization, with high-level diplomatic representation by the USA and its allies. During the Iraq-Iran war, Iraq used poisonous gases [96]: “Iraq's use of poison gases to regain the Fao Peninsula, captured by Iran in early 1986, was so blatant that the United Nations Security Council could no longer accept Baghdad's routine denials. After examining 700 Iranian casualties, the UN team of experts concluded that Iraq used mustard and nerve gases on many occasions." At this stage, the international community, the USA and its allies, and the United Nations Security Council were reluctant to take action against Saddam Hussein's regime in Iraq [96], 
despite the fact that this was not the first time of its use of poisonous gases. "Republican administration of President Ronald Reagan, it succeeded in getting the White House to frustrate the Senate's attempt to penalize Baghdad for violating the Geneva Protocol on Chemical Weapons, which it had signed" [96]. To this day, an international court has not been established to assess the atrocities and war crimes of Saddam Hussein's regime.

\subsection{OPs and the Civilian Population}

After WWII, police forces in most countries took to applying gases against civil demonstrations, as nonlethal weapons. Nerve gases were among these weapons. This is an opportune moment to question the juridical correctness of using gases against civilian populations, as the Geneva Protocol on Chemical Weapons prohibits the use of these gases in the battlefield against military personnel [120].

\section{Conclusions}

1) The design of the experiments described in [7] revealed that, before the exposure of olfactory organs to diazinon, Sex Pheromones did not evoke a full-fledged antipredator reflex through nervous signals in the following relevant systems: the $\mathrm{OE}, \mathrm{OB}, \mathrm{ON}$, and brain. The system yielded an adequate nervous reflex after exposure to Alarm Substance(s).

After exposure of the olfactory organs to diazinon, the Sex Pheromones provoked nervous activity in the OB, which can be decoded by the brain as signals from the exposure of the OE to Alarm Substance(s). This can partly explain the psychopathological action of OPs on the CNS, and, as a result, the inadequate reaction observed in fish (which manifested as an antipredator behavior rather than a homing or nesting behavior). These behavioral changes may be the source of the insufficient or demising reproducibility observed in fish stocks.

The chimerization of nerve signals happens after exposure to OPs in humans. Exposure can cause a chimeric reaction of Sex Pheromones in humans and prevent physiologically normal reactions. The continuous misrepresentation of nervous signals to the brain may lead to psychotic behavior in humans.

The results of the experiments described in [7] are directly connected to the behavioral changes observed after the exposure of the olfactory organ of fish to diazinon, and, as described previously for other OPs [105]-[110], it is possible that similar mechanisms play a significant role in the impairment of cognition and damage to the CNS in humans [32]-[34] [36] [97] [112]-[114]. Special attention should be paid to the possible mechanism underlying telencephalic lesions [106], which may arise from the direct transport of OPs through axoplasmic transport via ONs to the brain [16], thus causing brain lesions [114]. Telencephalic lesions induced by OPs can affect the electrolyte balance in the body, hart rhythm, blood pressure and other basal systems of regulation.

2) Even short-term, sublethal exposure to OPs has long-lasting, damaging effects on the nervous system [7] [97].

3) The denial by medical, insurance, juridical, and governing authorities of the impairment of cognition and damage to the CNS in humans after short-term exposure to a sublethal concentration of OPs [97] is groundless and even criminal.

4) A moratorium on, or even the prohibition of, the use of OPs as insecticides and pesticides should be accepted globally.

5) The use of all toxic chemicals by administrative authorities, such as police, against civilian populations should be stopped and regulated by the Geneva Protocol [120]. The use of gases against humans in civilian life is not acceptable, when at the same time the use of gases on the battlefield against military personnel is prohibited.

6) The Iraqi dictator Saddam Hussein was convicted for "crimes" and sentenced to death by the new Iraqi government, which is predominantly Kurdish. Undoubtedly, this conviction for "crimes" and the capital punishment that accompanied it were appropriate. However, the new Iraqi government prevented the assessment of the other crimes of this criminal dictator by an international tribunal. Therefore, the Iraqi dictator was not convicted by an international tribunal regarding his mass killings and crimes against humanity. During the Iraq-Iran war, which was initiated by Iraq, more than one million people were killed. A significant number of Iranian military personnel and civilians were killed by poisonous gases [96]. Several hundred thousands of USA military personnel were exposed to poisonous agents during the Gulf War against Iraq [97]. Who should be convicted for this crime?

7) The results of [7] suggest that the perception of external stimuli after exposure to OPs is misrepresented, 
and that the reaction to external events after exposure to OPs is inadequate. The veterans of the Gulf wars who are affected by the mysterious Persian Gulf War Syndrome, as well as other humans who were exposed to OPs, must receive adequate treatment and juridical protection.

\section{References}

[1] Brondz, I. (2014) Review: Can Toxic Substances Initiate Psychotic Behavior? Part I. Antimalarial Drugs. Open Journal of Preventive Medicine, 4, 561-572. http://dx.doi.org/10.4236/ojpm.2014.47066

[2] Brondz, I., Hamdani, E.H. and Døving, K.B. (2003) The Fish Olfactory System Used as an In-Line HPLC Neurophysiologic Detector NPD. 3rd International Symposium on Separation in BioSciences SBS 2003: A 100 Years of Chromatography, Moscow, 13-18 May 2003, 95.

[3] Brondz, I., Hamdani, E.H. and Døving, K.B. (2004) Neurophysiologic Detector (NPD)—A Selective and Sensitive Tool in High-Performance Liquid Chromatography. Chromatography B: Biomedical Sciences and Applications, 800, 41-47.

[4] Brondz, I., Hamdani, E.H. and Døving, K.B. (2004) International Scientific-Technical Conference Sensors Electronics and Microsystems Technology (SEMST-1), Odessa, 1-5 June 2004, Plenum Lecture, Abstract, 17.

[5] Brondz, I., Hamdani, E.H. and Døving, K.B. (2004) Isolation of a Fraction Inducing Activity in Neurones of "alarm Center” in the Olfactory Bulb of the Crucian carp, Carassius carassius L. The European Chemoreception Research Organization ECRO 2004 Congress, Dijon, 12-15 September 2004, Abstract, 3.

[6] Brondz, I., Karaliova, L. and Ekeberg, D. (2006) Biosensors as Electronic Compounds for Detector in the High-Performance Liquid Chromatography (HPLC). Electronic Components and Systems, 3, 25-27. (In Russian)

[7] Brondz, I. (2015) High-Performance Liquid Chromatograph (HPLC) Equipped with a Neurophysiological Detector (NPD) as a Tool for Studying Olfactory System Intoxication by the Organophosphate (OP) Pesticide Diazinon and the Influence of OP Pesticides on Reproduction. International Journal of Analytical Mass Spectrometry and Chromatography, 3, 14-24. http://dx.doi.org/10.4236/ijamsc.2015.31002

[8] Brondz, I. and Brondz, A. (2011) Suppression of Immunity by Some Pesticides, Xenobiotics, and Industrial Chemicals. In Vitro Model. Journal of Biophysical Chemistry, 2, 226-232. http://dx.doi.org/10.4236/jbpc.2011.23028

[9] von Frisch, K. (1942) Übereinen Schreckstoff der Fischhaut und seine biologische Bedeutung. ZeitschriftfürVergleichende Physiologie, 29, 46-145. http://dx.doi.org/10.1007/BF00304445

[10] Døving, K.B., Nordeng, Gr.H. and Oakley, B. (1974) Single Unit Discrimination of Fish Odours Released by Char (Salmo alpinus L.) Populations. Comparative Biochemistry and Physiology, 47A, 1051-1063. http://dx.doi.org/10.1016/0300-9629(74)90478-2

[11] Petroianu, G.A. (2009) The Synthesis of Phosphor Ethers: Who Was Franz Anton Voegeli? Pharmazie, 64, $269-275$.

[12] Benmoyal-Segal, L., Vander, T., Shifman, S., Bryk, B., Ebstein, R., Marcus, E.-L., Stessman, J., Darvasi, A., Herishanu, Y., Friedman, A. and Soreq, H. (2005) Acetylcholinesterase/Paraoxonase Interactions Increase the Risk of Insecticide-Induced Parkinson's Disease. The FASEB Journal, 19, 452-454. http://www.fasebj.org/cgi/doi/10.1096/fj.04-2106fje

[13] Quinn, D.M. (1987) Acetylcholinesterase: Enzyme Structure, Reaction Dynamics, and Virtual Transition Stats. Chemical Reviews, 87, 955-979. http://dx.doi.org/10.1021/cr00081a005

[14] Sussman, J.L., Harel, M., Frolow, F., Oefner, C., Goldman, A., Toker, L. and Silman, I. (1991) Atomic Structure of Acetylcholinesterase from Torpedo Californica: A Prototypic Acetylcholine-Binding Protein. Science, 253, 872-879. http://dx.doi.org/10.1126/science.1678899

[15] Holzgrabe, U. (1993) Struktur der Acetylcholinesterase. Abschied von einem Modell. Deutsche Apotheker Zeitung, 133, 1901-1902.

[16] Gross, G.W. and Kreutzberg, G.W. (1978) Rapid Axoplasmic Transport in the Olfactory Nerve of the Pike: I. Basic Transport Parameters for Proteins and Amino Acids. Brain Research, 139, 65-76. http://dx.doi.org/10.1016/0006-8993(78)90060-4

[17] Yang, R.S.H., Dauterman, W.C. and Hodgson, E. (1969) Enzymatic Degradation of Diazinon by Rat Liver Microsomes. Life Sciences, 8, 667-672. http://dx.doi.org/10.1016/0024-3205(69)90028-9

[18] Yang, R.S.H., Hodgson, E. and Dauterman, W.C. (1971) Metabolism in Vitro of Diazinon and Diazoxon in Rat Liver. Journal of Agricultural and Food Chemistry, 19, 10-13. http://dx.doi.org/10.1021/jf60173a040

[19] Yang, R.S.H., Hodgson, E. and Dauterman, W.C. (1971) Metabolism in Vitro of Diazinon and Diazoxon in Susceptible and Resistant Houseflies. Journal of Agricultural and Food Chemistry, 19, 14-19. http://dx.doi.org/10.1021/jf60173a041

[20] Janes, N.F., Machin, A.F., Quick, M.P., Rogers, H., Munday, D.E. and Cross, A.J. (1973) Toxic Metabolites of Diazi- 
non in Sheep. Journal of Agricultural and Food Chemistry, 21, 121-124. http://dx.doi.org/10.1021/jf60185a030

[21] Machin, A.F., Quick, M.P., Rogers, H. and Janes, N.F. (1972) An Isomer of Hydroxydiazinon Formed by Metabolism in Sheep. Bulletin of Environmental Contamination and Toxicology, 7, 270-272. http://dx.doi.org/10.1007/BF01684522

[22] Iverson, F., Grant, D.L. and Lacroix, J. (1975) Diazinon Metabolism in the Dog. Bulletin of Environmental Contamination and Toxicology, 13, 611-618. http://dx.doi.org/10.1007/BF01685188

[23] Miyata, T. and Matsumura, F. (1972) Organophosphate Degrading Enzymes in the Crude Supernatant Fraction from the Rat Liver. Journal of Agricultural and Food Chemistry, 20, 30-32. http://dx.doi.org/10.1021/jf60179a029

[24] Lichtenstein, E.P., Fuhremann, T.W., Hochberg, A.A., Zahlten, R.N. and Stratman, F.W. (1973) Metabolism of ${ }^{14}$ CParathion and ${ }^{14} \mathrm{C}$-Paraoxon with Fractions and Subfractions of Rat Liver Cells. Journal of Agricultural and Food Chemistry, 21, 416-424. http://dx.doi.org/10.1021/jf60187a008

[25] Menn, J.J. (1978) Comparative Aspects of Pesticide Metabolism in Plants and Animals. Environmental Health Perspectives, 27, 113-124. http://dx.doi.org/10.1289/ehp.7827113

[26] Mihara, K. and Miyamoto, J. (1974) Metabolism of Salithion ${ }^{\circledR}$ (2-Methoxy-4H-l,3,2-benzodioxaphosphorin-2-sulfide) in Rats and Plants. Agricultural and Biological Chemistry, 38, 1913-1924. http://dx.doi.org/10.1271/bbb1961.38.1913

[27] Mikami, N., Ohkawa, H. and Miyamoto, J. (1976) Photodecomposition of Surecide ${ }^{\circledR}$ (O-Ethyl O-4-Cyanophenyl Phenylphophonothioate) and Cyanox ${ }^{\circledR}$ (O,O-Dimethyl O-4-Cyanophenyl Phosphorothioate). Journal of Pesticide Science, 1, 273-281. http://dx.doi.org/10.1584/jpestics.1.273

[28] Edwards, D. (2006) Reregistration Eligibility Decision for Malathion. US Environmental Protection Agency—Prevention, Pesticides and Toxic Substances EPA 738-R-06-030.

http://www.epa.gov/pesticides/reregistration/REDs/malathion_red.pdf

[29] Schwartz, J.H. (1979) Axonal Transport: Components, Mechanisms, and Specificity. Annual Review of Neuroscience, 2, 467-504. http://dx.doi.org/10.1146/annurev.ne.02.030179.002343

[30] Soliman, S.A., Curley, A., Farmer, J. and Novak, R. (1986) In Vivo Inhibition of Chicken Brain Acetylcholinesterase and Neurotoxic Esterase in Relation to the Delayed Neurotoxicity of Leptophos and Cyanofenphos. Journal of Environmental Pathology, Toxicology and Oncology, 7, 211-224.

[31] Soliman, S.A. and Farmer, J.D. (1984) Delayed Neuropathy in Adult Peking Ducks Induced by Some Organophosphorus Esters. Journal of Toxicology and Environmental Health, 14, 789-801. http://dx.doi.org/10.1080/15287398409530627

[32] El-Sebae, A.H., Soliman, S.A., Ahmed, N.S. and Curley, A. (1981) Biochemical Interaction of Six OP Delayed Neurotoxicants with Several Neurotargets. Journal of Environmental Science and Health, Part B, Pesticides, Food Contaminants, and Agricultural Wastes, 16, 465-474. http://dx.doi.org/10.1080/03601238109372272

[33] Abou-Donia, M.B. (2003) Organophosphorus Ester-Induced Chronic Neurotoxicity. Archives of Environmental Health: An International Journal, 58, 484-497. http://dx.doi.org/10.3200/AEOH.58.8.484-497

[34] Behan, P.O. and Haniffah, B.A.G. (1994) Chronic Fatigue Syndrome: A Possible Delayed Hazard of Pesticide Exposure. Clinical Infectious Diseases, 18, S54. http://dx.doi.org/10.1093/clinids/18.supplement_1.s54

[35] Briggs, N.C. and Levine, P.H. (1994) A Comparative Review of Systemic and Neurological Symptomatology in 12 Outbreaks Collectively Described as Chronic Fatigue Syndrome, Epidemic Neuromyasthenia, and Myalgic Encephalomyelitis. Clinical Infectious Diseases, 18, S32-S42. http://dx.doi.org/10.1093/clinids/18.Supplement_1.S32

[36] Racciatti, D., Vecchiet, J., Ceccomancini, A., Ricci, F. and Pizzigallo, E. (2001) Chronic Fatigue Syndrome Following a Toxic Exposure. The Science of the Total Environment, 270, 27-31. http://dx.doi.org/10.1016/S0048-9697(00)00777-4

[37] Miranda-Contreras, L., Gómez-Pérez, R., Rojas, G., Cruz, I., Berrueta, L., Salmen, S., Colmenares, M., Barreto, S., Balza, A., Zavala, L., Morales, Y., Molina, Y., Valeri, L., Contreras, C.A. and Osuna, J.A. (2013) Occupational Exposure to Organophosphate and Carbamate Pesticides Affects Sperm Chromatin Integrity and Reproductive Hormone Levels among Venezuelan Farm Workers. Journal of Occupational Health, 55, 195-203. http://dx.doi.org/10.1539/joh.12-0144-FS

[38] Poongothai, S., Ravikrishnan, R. and Murthy, P. (2007) Endocrine Disruption and Perspective Human Health Implications: A Review. The Internet Journal of Toxicology, 4. https://ispub.com/IJTO/4/2/3638

[39] Karalliedde, L. (1999) Organophosphorus Poisoning and Anaesthesia. Anaesthesia, 54, 1073-1088. http://dx.doi.org/10.1046/j.1365-2044.1999.01061.x

[40] Coyle, P.K., Krupp, L.B., Doscher, C. and Amin, K. (1994) Borrelia burgdorferi Reactivity in Patients with Severe Persistent Fatigue Who Are from a Region in Which Lyme Disease Is Endemic. Clinical Infectious Diseases, 18, S24S27. 
[41] Eyer, P. (1995) Neuropsychopathological Changes by Organophosphorus Compounds-A Review. Human \& Experimental Toxicology, 14, 857-864. http://dx.doi.org/10.1177/096032719501401101

[42] Bazylewicz-Walczak, B., Majczakowa, W. and Szymczak, M. (1999) Behavioral Effects of Occupational Exposure to Organophosphorous Pesticides in Female Greenhouse Planting Workers. Neuro Toxicology, 20, 819-826.

[43] Frawley, J.P., Fuyat, H.N., Hagan, E.C., Blake, J.R. and Fitzhugh, O.G. (1957) Marked Potentiation in Mammalian Toxicity from Simultaneous Administration of Two Anticholinesterase Compounds. Journal of Pharmacology and Experimental Therapeutics, 121, 96-106.

[44] Karczmar, A. (1998) Invited Review Anticholinesterases: Dramatic Aspects of Their Use and Misuse. Neurochemistry International, 32, 401-411. http://dx.doi.org/10.1016/S0197-0186(97)00123-X

[45] Garbellini, G.S., Uliana, C.V. and Yamanaka, H. (2013) Interaction of Organophosphorus Pesticides with DNA Nucleotides on a Boron-Doped Diamond Electrode. Journal of the Brazilian Chemical Society, 24, 1942-1949.

[46] Kermen, F., Franco, L.M., Wyatt, C. and Yaksi, E. (2013) Neural Circuits Mediating Olfactory-Driven Behavior in Fish. Frontiers in Neural Circuits, 7. http://dx.doi.org/10.3389/fncir.2013.00062

[47] Hara, T.J. and Zielinski, B. (2007) Olfaction. In: Sensory Systems Neuroscience, Elsevier Academic Press, Oxford, 143.

[48] Sheldon, R.E. (1912) The Olfactory Tracts and Centers in Teleosts. Journal of Comparative Neurology, 22, $177-339$. http://dx.doi.org/10.1002/cne.900220301

[49] Finger, T.E. (1975) The Distribution of the Olfactory Tracts in the Bullhead Catfish, Ictalurus nebulosus. Journal of Comparative Neurology, 161, 125-141. http://dx.doi.org/10.1002/cne.901610110

[50] Bass, A.H. (1981) Telencephalic Efferents in Channel Catfish, Ictalurus punctatus: Projections to the Olfactory Bulb and Optic Tectum. Brain, Behavior and Evolution, 19, 1-16. http://dx.doi.org/10.1159/000121631

[51] von Bartheld, C.S., Meyer, D.L., Fiebig, E. and Ebbesson, S.O. (1984) Central Connections of the Olfactory Bulb in the Goldfish, Carassius auratus. Cell and Tissue Research, 238, 475-487. http://dx.doi.org/10.1007/BF00219862

[52] Hamdani, E.H., Stabell, O.B., Alexander, G. and Doving, K.B. (2000) Alarm Reaction in the Crucian Carp Is Mediated by the Medial Bundle of the Medial Olfactory Tract. Chemical Senses, 25, 103-109. http://dx.doi.org/10.1093/chemse/25.1.103

[53] Hamdani, E.H., Lastein, S., Gregersen, F. and Doving, K.B. (2008) Seasonal Variations in Olfactory Sensory NeuronsFish Sensitivity to Sex Pheromones Explained? Chemical Senses, 33, 119-123. http://dx.doi.org/10.1093/chemse/bjm072

[54] Browne, J.V. (2008) Chemosensory Development in the Fetus and Newborn. Newborn \& Infant Nursing Reviews, 8, 180-186. http://dx.doi.org/10.1053/j.nainr.2008.10.009

[55] Fishelson, L., Golani, D., Galil, B. and Goren, M. (2010) Comparison of the Nasal Olfactory Organs of Various Species of Lizardfishes (Teleostei: Aulopiformes: Synodontidae) with Additional Remarks on the Brain. International Journal of Zoology, 2010, Article ID: 807913. http://dx.doi.org/10.1155/2010/807913

[56] Kleerekoper, H. (1969) Olfaction in Fishes. Indiana University Press, Bloomington.

[57] Hara, T.J. (1975) Olfaction in Fish. Progress in Neurobiology, 5, 271-335. http://dx.doi.org/10.1016/0301-0082(75)90014-3

[58] Hara, T.J. (1994) Olfaction and Gustation in Fish: An Overview. Acta Physiologica Scandinavica, 152, 207-217. http://dx.doi.org/10.1111/j.1748-1716.1994.tb09800.x

[59] Hara, T.J. (2005) Olfactory Responses to Amino Acids in Rainbow Trout: Revisited. In: Reutter, K. and Kapoor, B.G. Eds., Fish Chemosenses, Science Publishers, Enfield, 32-64.

[60] Atema, J. (1983) Chemical Senses, Chemical Signals, and Feeding Behavior in Fishes. In: Bardach, J.E., Magnuson, J.J., May, R.C. and Reinhart, J.M., Eds., Fish Behavior and Its Use in the Capture and Culture of Fishes (ICLARMConference 5), International Center for Living Aquatic Resources Management, Manila, 57-101.

[61] Hara, T.J. and Zielinski, B.S. (1989) Structural and Functional Development of the Olfactory Organ in Teleosts. Transaction of the American Fishery Society, 118, 183-194. http://dx.doi.org/10.1577/1548-8659(1989)118<0183:SAFDOT>2.3.CO;2

[62] von Frisch, K. (1938) Zur Psychologie des Fish-Schwarmes. Naturwissenschaften, 26, 601-606. http://dx.doi.org/10.1007/BF01590598

[63] Johnson, K.M. (1997) Human Sexual Motivation. California State University, Northridge. http://www.csun.edu/ vcpsy00h/students/sexmotiv.htm

[64] Kohl, J.V., Atzmueller, M., Fink, B. and Grammer, K. (2001) Human Pheromones: Integrating Neuroendocrinology and Ethology. Neuroendocrinology Letters, 22, 309-321. 
[65] Taylor, G.T. (1980) Sex Pheromones and Aggressive Behavior in Male Rats. Animal Learning \& Behavior, 8, 485490. http://dx.doi.org/10.3758/BF03199638

[66] Gower, D.B., Nixon, A., Jackman, P.J.H. and Mallet, A.I. (1986) Transformation of Steroids by Axillary Coryneform Bacteria. International Journal of Cosmetic Science, 8, 149-158. http://dx.doi.org/10.1111/j.1467-2494.1986.tb00443.x

[67] Troccaz, M. (2009) The Biosynthetic Pathway of Sulfur-Containing Molecules in Human Axillary Malodor: From Precursors to Odorous Volatiles. Thèse de doctorat, Univ. Genève, No. Sc. 4102. http://archive-ouverte.unige.ch/unige:4563

[68] Holman, L. (2010) Queen Pheromones: The Chemical Crown Governing Insect Social Life. Communicative \& Integrative Biology, 3, 558-560. http://dx.doi.org/10.4161/cib.3.6.12976

[69] Wilson, E.O. and Regnier Jr., F.E. (1971) The Evolution of the Alarm-Defense System in the Formicine Ants. The American Naturalist, 105, 279-289. http://dx.doi.org/10.1086/282724

[70] Holman, L., Jørgensen, C.G., Nielsen, J. and d’Ettorre, P. (2010) Identification of an Ant Queen Pheromone Regulating Worker Sterility. Proceedings of the Royal Society of London Proceedings B: Biological, 277, 3793-3800. http://rspb.royalsocietypublishing.org/content/277/1701 http://dx.doi.org/10.1098/rspb.2010.0984

[71] Smith, A.A., Hölldober, B. and Liebig, J. (2009) Cuticular Hydrocarbons Reliably Identify Cheaters and Allow Enforcement of Altruism in a Social Insect. Current Biology, 19, 78-81. http://dx.doi.org/10.1016/j.cub.2008.11.059

[72] Peeters, C. and Liebig, J. (2009) Fertility Signaling as a General Mechanism of Regulating Reproductive Division of Labor in Ants. In: Gadau, J. and Fewell, J., Eds., Organization of Insect Societies: From Genome to Socio-Complexity, Harvard University Press, Cambridge, 220-242.

[73] Dapporto, L., Romana Dani, F. and Turillazzi, S. (2007) Social Dominance Molds Cuticular and Egg Chemical Blends in a Paper Wasp. Current Biology, 17, 504-505. http://dx.doi.org/10.1016/j.cub.2007.05.002

[74] Amsalem, E., Twele, R., Francke, W. and Hefetz, A. (2009) Reproductive Competition in the Bumble-Bee Bombus terrestris: Do Workers Advertise Sterility? Proceedings of the Royal Society of London Proceedings B: Biological, 276, 1295-1304.

[75] Robinson, G.E., Winston, M.L., Huang, Z. and Pankiw, T. (1998) Queen Mandibular Gland Pheromone Influences Worker Honey Bee (Apis mellifera L.) Foraging Ontogeny and Juvenile Hormone Titers. Journal of Insect Physiology, 44, 685-692. http://www.ncbi.nlm.nih.gov/pubmed/12769952 http://dx.doi.org/10.1016/S0022-1910(98)00040-7

[76] Beggs, K.T., Glendining, K.A., Marechal, N.M., Vergoz, V., Nakamura, I., Slessor, K.N. and Mercer, A.R. (2007) Queen Pheromone Modulates Brain Dopamine Function in Worker Honey Bees. Proceedings of the National Academy of Sciences of the United States of America, 104, 2460-2464. http://www.ncbi.nlm.nih.gov/pmc/articles/PMC1892986/ http://dx.doi.org/10.1073/pnas.0608224104

[77] Vergoz, V., Schreurs, H.A. and Mercer, A.R. (2007) Queen Pheromone Blocks Aversive Learning in Young Worker Bees. Science, 317, 384-386. http://dx.doi.org/10.1126/science.1142448

[78] Novotny, M.V. (2003) Pheromones, Binding Proteins and Receptor Responses in Rodents. Biochemical Society Transactions, 31, 117-122. http://dx.doi.org/10.1042/bst0310117

[79] Korb, J., Weil, T., Hoffman, K., Foster, K.R. and Rehli, M. (2009) A Gene Necessary for Reproductive Suppression in Termites. Science, 324, 758. http://dx.doi.org/10.1126/science.1170660

[80] Jarosch, A., Stole, E., Crewe, R. and Moritz, R.F.A. (2011) Alternative Splicing of a Single Transcription Factor Drives Selfish Reproductive Behavior in Honeybee Workers (Apis mellifera). Proceedings of the National Academy of Sciences of the United States of America, 108, 15282-15287. http://dx.doi.org/10.1073/pnas.1109343108

[81] Van Zweden, J.S., Bonckaert, W., Wenseleers, T. and d’Ettorre, P. (2013) Queen Signaling in Social Wasps. Evolution, 68, 976-986. http://dx.doi.org/10.1111/evo.12314

[82] Koenig, W.D., Mumme, R.L., Stanback, T. and Pitelka, F.A. (1995) Patterns and Consequences of Egg Destruction among Joint-Nesting Acorn Woodpeckers. Animal Behaviour, 50, 607-621. http://dx.doi.org/10.1016/0003-3472(95)80123-5

[83] Cant, M.A. (2000) Social Control of Reproduction in Banded Mongooses. Animal Behavior, 59, 147-158. http://dx.doi.org/10.1006/anbe.1999.1279

[84] Spiering, P.A., Somers, M.J., Maldonado, J.E., Wildt, D.E. and Gunter, M.S. (2010) Reproductive Sharing and Proximate Factors Mediating Cooperative Breeding in the African Wild Dog (Lycaon pictus). Behavioral Ecology Sociobiology, 64, 583-592. http://dx.doi.org/10.1007/s00265-009-0875-6

[85] Beehner, J.C. and Lu, A. (2013) Reproductive Suppression in Female Primates: A Review. Evolutionary Anthropology, 22, 226-238. http://dx.doi.org/10.1002/evan.21369 
[86] Bowman, L., Dilley, S.R. and Keverne, E.B. (1978) Suppression of Oestrogen-Induced LH Surges by Social Subordination in Talapoin Monkeys. Nature, 275, 56-58. http://dx.doi.org/10.1038/275056a0

[87] Kirk-Smith, M., Booth, D.A., Carroll, D. and Davies, P. (1978) Human Social Attitudes Affected by Androstenol. Research Communications in Psychology, Psychiatry and Behavior, 3, 379-384.

[88] Filsinger, E.E., Braun, J.J. and Monte, W.C. (1990) Sex Differences in Response to the Odor of Alpha Androstenone. Perceptual and Motor Skills, 70, 216-218. http://dx.doi.org/10.2466/pms.1990.70.1.216

[89] Patočka, J. (2010) Kdo Syntetizoval První Organofosforový Inhibitor Acetylcholinesterasy? Vojenské Zdravotnické Listy, 123, 126-128.

[90] Petroianu, G.A. (2010) Toxicity of Phosphor Esters: Willy Lange (1900-1976) and Gerda von Krueger (1907-after 1970). Pharmazie, 65, 776-780.

[91] Fitzgerald, G.J. (2008) Chemical Warfare and Medical Response during World War I. American Journal of Public Health, 98, 611-625. http://www.ncbi.nlm.nih.gov/pmc/articles/PMC2376985/ http://dx.doi.org/10.2105/AJPH.2007.111930

[92] The Nuremberg Trials. http://www.ushmm.org/outreach/en/article.php?ModuleId=10007722

[93] The International Military Tribunal for Germany. Contents of the Nuremberg Trials Collection. http://avalon.law.yale.edu/subject_menus/imt.asp

[94] The Allies and the Use of Gas in WWII. http://rense.com/general83/gas.htm

[95] Kozakiewicz, P. (2014) Editorials Moscow Theater Crisis: Unknown Chemical Agent Revisited. CBRNePortal. http://www.cbrneportal.com/moscow-theater-crisis-unknown-chemical-agent-revisited/

[96] Hiro, D. (2002) Iraq and Poison Gas. The Nation. http://www.thenation.com/article/iraq-and-poison-gas/

[97] Kennedy, K. (2012) Study: Wind Blew Deadly Gas to US Troops in Gulf War. USA TODAY. http://www.usatoday.com/story/news/world/2012/12/13/sarin-gas-gulf-war-veterans/1766835/

[98] Koeppel, B. (2015) US Nerve Gas Hit Our Own Troops. Newsweek. http://www.newsweek.com/how-us-nerve-gassed-its-own-troops-then-covered-it-317250

[99] Hamdani, E.H. and Døving, K.B. (2003) Sensitivity and Selectivity of Neurons in the Medial Region of the Olfactory Bulb to Skin Extract from Conspecifics in Crucian Carp, Carassius carassius. Chemical Senses, 28, 181-189. http://dx.doi.org/10.1093/chemse/28.3.181

[100] Lastein, S., Hamdani, E.H. and Døving, K.B. (2008) Single Unit Responses to Skin Odorants from Conspecifics and Heterospecifics in the Olfactory Bulb of Crucian Carp Carassius carassius. The Journal of Experimental Biology, 211, 3529-3535. http://dx.doi.org/10.1242/jeb.018739

[101] Lastein, S. (2008) Olfactory Processing of Sex and Alarm Cues in the Crucian Carp Carassius carassius. PhD Thesis, University of Oslo, Oslo.

[102] Dittman, A.H. and Quinn, T.P. (1996) Homing in Pacific Salmon: Mechanisms and Ecological Basis. The Journal of Experimental Biology, 199, 83-91.

[103] Brown, G.E. and Smith, R.J.F. (1997) Conspecific Skin Extracts Elicit Antipredator Responses in Juvenile Rainbow Trout (Oncorhynchus mykiss). Canadian Journal of Zoology, 75, 1916-1922. http://dx.doi.org/10.1139/z97-821

[104] Heczko, E.J. and Seghers, B.H. (1981) Effects of Alarm Substance on Schooling in the Common Shiner (Notropis cornutus, Cyprinidae). Environmental Biology of Fishes, 6, 25-29. http://dx.doi.org/10.1007/BF00001796

[105] Scholz, N.L., Truelove, N.K., French, B.L., Berejikian, B.A., Quinn, T.P., Casillas, E. and Collier, T.K. (2000) Diazinon Disrupts Antipredator and Homing Behaviors in Chinook Salmon (Oncorhynchus tshawytscha). Canadian Journal of Fisheries and Aquatic Sciences, 57, 1911-1918. http://dx.doi.org/10.1139/f00-147

[106] Davis, R.E., Reynolds, R.C. and Ricks, A. (1978) Suppression Behavior Increased by Telencephalic Lesions in the Teleost, Macropodus opercularis. Behavioral Biology, 24, 32-48. http://dx.doi.org/10.1016/S0091-6773(78)92866-3

[107] Sandahl, J.F., Baldwin, D.H., Jenkins, J.J. and Scholz, N.L. (2004) Odor-Evoked Field Potentials as Indicators of Sublethal Neurotoxicity in Juvenile Coho Salmon (Oncorhynchus kisutch) Exposed to Copper, Chlorpyrifos, or Esfenvalerate. Canadian Journal of Fisheries and Aquatic Sciences, 61, 404-413. http://dx.doi.org/10.1139/f04-011

[108] Sharifian, I., Rastiannasab, A. and Gandomkar, H. (2015) Effects of Diazinon on Some Immunological Components of Common Carp, Cyprinus carpio Juveniles. Comparative Clinical Pathology, 24, 1339-1341. http://dx.doi.org/10.1007/s00580-015-2076-1

[109] Buřič, M., Kouba, A., Máchová, J., Mahovská, I. and Kozák, P. (2013) Toxicity of the Organophosphate Pesticide Diazinon to Crayfish of Differing Age. International Journal of Environmental Science and Technology, 10, 607-610. http://dx.doi.org/10.1007/s13762-013-0185-4

[110] Moore, D.R.J. and Teed, R.S. (2013) Risks of Carbamate and Organophosphate Pesticide Mixtures to Salmon in the 
Pacific Northwest. Integrated Environmental Assessment and Management, 9, 70-78. http://dx.doi.org/10.1002/ieam.1329

[111] Huang, B. (2015) Chronic Behavioral and Cognitive Deficits in a Rat Survival Model of Organophosphate Toxicity. VCU Theses and Dissertations, VCU University Archives Paper 3696. http://scholarscompass.vcu.edu/etd/3696

[112] Overstreet, D.H. (2000) Organophosphate Pesticides, Cholinergic Function and Cognitive Performance in Advanced Age. Neurotoxicology, 21, 75-81.

[113] Richardson, R.J., Worden, R.M., Wijeyesakere, S.J., Hein, N.D., Fink, J.K. and Makhaeva, G.F. (2015) Chapter 63, Neuropathy Target Esterase as a Biomarkers and Biosensor of Delayed Neuropathic Agents. In: Gupta, R.C., Ed., Handbook of Toxicology of Chemical Warfare Agents, Second Edition, Academic Press, London, San Diego, Waltham and Oxford, 935-952.

[114] Reneman, L., Schagen, S.B., Mulder, M., Mutsaerts, H.J., Hageman, G. and de Ruiter, M.B. (2015) Cognitive Impairment and Associated Loss in Brain White Microstructure in Aircrew Members Exposed to Engine Oil Fumes. Brain Imaging and Behavior, Published Online. http://link.springer.com/article/10.1007\%2Fs11682-015-9395-3

[115] Mackenzie, S.R., Clark, J., Harrison, V. and Abraham, K. (2007) Cognitive Impairment Following Exposure to Organophosphate Pesticides: A Pilot Study. Journal of Occupational Health \& Safety-Australia \& New Zealand, 23, 133142.

[116] Mackenzie, S.R., McManus, I.C., Harrison, V. and Mason, O. (2013) Neurobehavioral Problems Following Low-Level Exposure to Organophosphate Pesticides: A Systematic and Meta-Analytic Review. Critical Reviews in Toxicology, 43, 21-44. http://informahealthcare.com/doi/pdf/10.3109/10408444.2012.738645 http://dx.doi.org/10.3109/10408444.2012.738645

[117] Aspmo, R., Eklo, O.M., Lode, O., Brondz, I., Johnsen, Å.M. and Olsen, D. (1991) Avrenning av plantevernmidler fra jordbruksarealer. In: Plantevernmidelforurensning til jord og vann, Underveis-seminar Nr. 2, 100-107.

[118] Lode, O., Eklo, O.M., Brondz, I. and Johnsen, Å.M. (1991) Vertikal transport av plantevernmiddel i jord i feltforsøk. In: Plantevernmidelforurensning til jord og vann, Underveis-seminar Nr. 2, 109-115.

[119] Eklo, O.M., Riise, G., Brondz, I., Lode, O., Salbo, B., Pettersen, M.N. and Johnsen, Å.M. (1991) Mobilitet og nedbrytning av DIKLORPROP i søyleforsøk. In: Plantevernmidelforurensning til jord og vann, Underveis-seminar Nr. 2, 116-126.

[120] Geneva Protocol (1925) Protocol Entered into Force on 8 February 1928. http://www.un.org/disarmament/WMD/Bio/1925GenevaProtocol.shtml

[121] UN Resolution 687. https://www.google.com/\#q=un+resolution+687+summary 